\title{
PENGARUH MODEL LEARNING CYCLE 5E (ENGAGE, EXPLORE, EXPLAIN, ELABORATION, \& EVALUATE) TERHADAP KEMAMPUAN BERPIKIR KRITIS PESERTA DIDIK KELAS X MAN 1 MATARAM
}

\author{
Baiq Rizkia Ayu Latifa, Ni Nyoman Sri Putu Verawati, Ahmad Harjono \\ Program Studi Pendidikan Fisika \\ FKIP, Universitas Mataram \\ Jalan Majapahit no. 62, Mataram \\ Email : baiqralatifa@gmail.com
}

\begin{abstract}
This study aims to determine the effect of learning cycle 5E model (Engage, Explore, Explain, Elaboration, \& Evaluate) on student's critical thinking skills of class X in MAN 1 Mataram. This research type is quasi experiment with research design untreated control group with pretest and posttest design. The sample was selected by cluster random sampling technique and obtained X MIA 1 class as experiment class using learning cycle $5 E$ model and X MIA 2 class as control class using cooperative learning type STAD model. The critical thinking ability's data collected by essay test that are 5 questions that have been tested for validation, reliability, difficulty level, and index of discrimination. Researchers used homogeneity test, normality test, $t$-test polled variance, and $N$-Gain test as statistical test. $N$-Gain test are used to determine the improvement of critical thinking skills in each indicator. The experimental class get improvement result in medium category for all indicators, while the control class get improvement in medium category on three indicators and two other indicators in low category. Based on result of hypothesis test can be concluded that there is effect of learning cycle $5 E$ model to critical thinking ability of students.
\end{abstract}

Keyword: Learning Cycle 5E Model (Engage, Explore, Explain, Elaboration, \& Evaluate), Critical Thinking Skill.

\section{PENDAHULUAN}

Fisika dipandang sebagai suatu proses dan produk. Fisika sebagai proses berarti pemahaman mengenai bagaimana informasi ilmiah fisika dapat diperoleh dengan melakukan pengamatan, pengukuran, penyelidikan dan publikasi. Sedangkan fisika sebagai produk berarti fisika sebagai kumpulan pengetahuan berupa fakta, konsep, prinsip, hukum, rumus, dan teori.

Suprijono (2011) menyatakan bahwa banyak peserta didik sebenarnya mampu menyajikan tingkat hafalan yang baik terhadap materi ajar yang diterima namun pada kenyataannya mereka tidak memahaminya. Pembelajaran fisika tidak hanya sekedar menghafal, namun perlunya pemahaman yang lebih untuk meningkatkan kemampuan berpikir yang dimilikinya.

Pembelajaran fisika juga seyogyanya mempertimbangkan strategi atau metode pembelajaran yang efektif dan efisien untuk meningkatkan kemampuan berpikir peserta didik. Sesuai dengan tuntutan kurikulum 2013 yang menginginkan adanya peningkatan pada indikator kemampuan berpikir kritis seperti kemampuan mengevaluasi. Menginovasi proses pembelajaran merupakan cara yang tepat bagi guru untuk mengembangkan kemampuan berpikir kritis. Hal yang dapat dilakukan adalah dengan menggunakan model pembelajaran yang sesuai.

Berdasarkan hasil observasi melalui wawancara dengan salah seorang guru fisika di MAN 1 Mataram menunjukkan bahwa proses pembelajaran yang diterapkan selama ini belum mampu meningkatkan kemampuan berpikir kritis, karena latihan untuk peningkatan kemampuan tersebut belum dilakukan. Penyebab lainnya adalah karena model pembelajaran yang digunakan terkesan monoton dan kurang variatif.

Menggunakan model pembelajaran yang tepat adalah cara yang perlu dilakukan. Salah satu model pembelajaran alternatif yang dapat digunakan adalah model learning cycle 5E. Model ini dikembangkan untuk menciptakan aktivitas pembelajaran yang efektif dan efisien dalam rangka meningkatkan kemampuan berpikir kritis peserta didik. Model learning cycle $5 E$ yang digunakan ini memiliki lima tahapan yakni engage, explore, explain, elaboration, \& evaluate. 
Tahap engage bertujuan untuk mempersiapkan peserta didik agar terkondisikan dalam menempuh fase berikutnya dengan jalan mengeksplorasi pengetahuan awal dan ide-ide mereka. Pada tahap explore peserta didik diberi kesempatan untuk bekerjasama dalam kelompok-kelompok kecil melakukan kegiatan-kegiatan seperti praktikum dan telaah literatur. Explain adalah tahap dimana guru mendorong peserta didik untuk menjelaskan konsep dengan kalimat mereka sendiri. Pada tahap elaboration peserta didik mengembangkan konsep dan keterampilan dalam situasi baru. Tahap akhir yaitu evaluate guru menilai apakah peserta didik telah mencapai tujuan pembelajaran.

Salah satu kelebihan dari model learning cycle $5 E$ adalah dapat mengembangkan potensi masingmasing individu karena dapat memfasilitasi perubahan konseptual peserta didik (Hikmawati, 2015), karena mereka diwajibkan untuk melakukan analisis pada fase explore, penerapan konsep pada situasi yang baru pada fase elaboration, dan evaluasi untuk setiap pembelajaran yang dilakukan. Dengan demikian kemampuan berpikir kritis pada beberapa indikator dapat meningkat.

Penelitian mengenai kemampuan berpikir kritis dirasa penting karena merupakan modal bagi peserta didik untuk dapat mengembangkan pengetahuannya secara luas. Handriani, et al (2015) menyatakan bahwa kemampuan berpikir kritis adalah suatu proses kognisi peserta didik secara mendalam yang diterapkan dalam kegiatan pembelajaran yang memenuhi beberapa indikator. Kemampuan berpikir seseorang juga menentukan keberhasilan dalam hidupnya.

Berpikir kritis merupakan proses dan kemampuan yang dilibatkan dalam membuat keputusan secara rasional apa yang harus dilakukan dan apa yang harus dipercaya. Kemampuan berpikir kritis yang baik dapat memberikan rekomendasi yang baik untuk melakukan suatu tindakan (Gunawan \& Liliasari, 2012). Menurut Johnson (2008) Berpikir kritis adalah sebuah proses yang terarah dan jelas yang digunakan dalam kegiatan mental seperti memecahkan masalah, mengambil keputusan, membujuk, menganalisis asumsi, dan melakukan penelitian ilmiah. Adapun indikator yang digunakan sebanyak lima indikator yag mengacu pada indikator kemampuan berpikir kritis Ennis (2011) yaitu klarifikasi dasar, keputusan dasar, inferensi, penjelasan lebih lanjut, menalar dan pengintegrasian.
Penelitian lebih lanjut diperlukan untuk mengetahui pengaruh model learning cycle $5 E$ (engage, explore, explain, elaboration, \& evaluate) terhadap kemampuan berpikir kritis peserta didik kelas X MAN 1 Mataram.

\section{METODE PENELITIAN}

Penelitian ini menggunakan penelitian jenis quasi experiment (eksperimen semu). Menurut Setyosari (2013), penelitian jenis eksperimen semu merupakan penelitian untuk menguji hubungan sebabakibat, dimana peneliti memberikan perlakuan kepada subjek untuk menentukan apakah perlakuan tersebut memiliki dampak atau pengaruh pada variabel atau faktor hasil tertentu. Adapun desain penelitian yang digunakan yaitu untreated control group design with pretest and postest dengan rancangan pada Tabel 1 sebagai berikut.

Tabel 1. Rancangan desain penelitian

\begin{tabular}{cccc}
\hline \multicolumn{1}{c}{ Kelas } & Tes awal & Perlakuan & Tes akhir \\
\hline Eksperimen & $\mathrm{O}_{1}$ & $\mathrm{X}_{1}$ & $\mathrm{O}_{3}$ \\
\hline Kontrol & $\mathrm{O}_{2}$ & $\mathrm{X}_{2}$ & $\mathrm{O}_{4}$ \\
\hline & & Sumber : Setyosari (2013)
\end{tabular}

Keterangan :

$\mathrm{O}_{1}$ : Pemberian tes awal pada kelas eksperimen sebelum diberikan perlakuan.

$\mathrm{O}_{2}$ : Pemberian tes akhir pada kelas eksperimen setelah diberikan perlakuan.

$\mathrm{O}_{3}$ : Pemberian tes awal pada kelas kontrol sebelum diberikan perlakuan

$\mathrm{O}_{4}$ : Pemberian tes akhir pada kelas kontrol setelah diberikan perlakuan.

$\mathrm{X}_{1} \quad$ : Perlakuan berupa model learning cycle $5 E$

$\mathrm{X}_{2}$ : Perlakuan berupa model cooperative learning tipe $S T A D$

Populasi pada penelitian ini adalah seluruh peserta didik kelas X MAN 1 Mataram. Teknik pengambilan sampel yang digunakan adalah teknik cluster random sampling, sehingga didapatkan peserta didik kelas X MIA 1 sebagai kelompok eksperimen dan peserta didik kelas X MIA 2 sebagai kelompok kontrol.

Pengumpulan data dilakukan dengan cara memberikan tes uraian sebanyak lima soal berdasarkan indikator kemampuan berpikir kritis. Adapun teknik analisis data yang digunakan adalah sebagai berikut. 
1. Menghitung homogenitas sampel dengan menggunakan uji varians atau uji-F.

2. Menghitung uji normalitas data dengan Uji Chi Kuadrat.

3. Uji N-gain dihitung dengan rumus $\mathrm{N}$-gain ternormalisasi

4. Kemampuan berpikir kritis dianalisis yang mengacu pada persamaan (Yuliati, 2011),

$$
\text { nilai }=\frac{\text { skor yang diperoleh }}{\text { skor maksimal }} \times 100
$$

Kategori skala perolehan yang didapatkan adalah jika nilai yang didapatkan $81,25<\mathrm{x} \leq 100$ maka sangat kritis, $62,50<\mathrm{x} \leq 81,25$ berkategori kritis, $43,75<\mathrm{x} \leq 62,50$ kurang kritis, dan untuk nilai $25,00<\mathrm{x} \leq 43,75$ berkategori sangat kurang kritis.

5. Hipotesis diuji dengan menggunakan $t$-test polled varians

\section{HASIL DAN PEMBAHASAN}

Penelitian ini bertujuan untuk mengetahui pengaruh model learning cycle 5E (Engage, Explore, Explain, Elaboration, \& Evaluate) terhadap kemampuan berpikir kritis peserta didik kelas $\mathrm{X}$ di MAN 1 Mataram. Data yang diperoleh merupakan nilai hasil tes awal dan tes akhir yang dilakukan pada kelas eksperimen dan kontrol. Adapun nilai yang diperoleh masing-masing kelas untuk setiap indikator dapat dilihat pada Tabel 2 berikut.

Tabel 2. Nilai Kelas Eksperimen dan Kelas Kontrol

Masing-masing Indikator Kemampuan Berpikir Kritis

\begin{tabular}{lcccc}
\hline \multicolumn{1}{c}{ Indikator } & \multicolumn{2}{c}{ Kelas } & \multicolumn{2}{c}{ Kelas Kontrol } \\
& \multicolumn{2}{c}{ Eksperimen } & & \\
\cline { 2 - 5 } & $\begin{array}{c}\text { Tes } \\
\text { awal }\end{array}$ & $\begin{array}{c}\text { Tes } \\
\text { akhir }\end{array}$ & $\begin{array}{c}\text { Tes } \\
\text { awal }\end{array}$ & $\begin{array}{c}\text { Tes } \\
\text { akhir }\end{array}$ \\
\hline $\begin{array}{l}\text { Klarifikasi } \\
\text { dasar }\end{array}$ & 44,35 & 71,77 & 45,16 & 49,19 \\
$\begin{array}{l}\text { Keputusan } \\
\text { dasar }\end{array}$ & 42,74 & 67,74 & 33,06 & 53,23 \\
$\begin{array}{l}\text { Inferensi } \\
\begin{array}{l}\text { Penjelasan } \\
\text { lebih lanjut }\end{array}\end{array}$ & 25,00 & 70,97 & 26,61 & 50,00 \\
$\begin{array}{l}\text { Menalar dan } \\
\text { pengintegrasi }\end{array}$ & 16,94 & 42,74 & 15,32 & 29,03 \\
an & & & & 51,61 \\
\hline
\end{tabular}

Data tersebut kemudian diolah dengan menggunakan rumus $\mathrm{N}$-gain yang bertujuan untuk membandingkan peningkatan masing-masing indikator kemampuan berpikir kritis dari kelas eksperimen dan kelas kontrol. Sehingga diperoleh data N-gain untuk masing-masing indikator pada

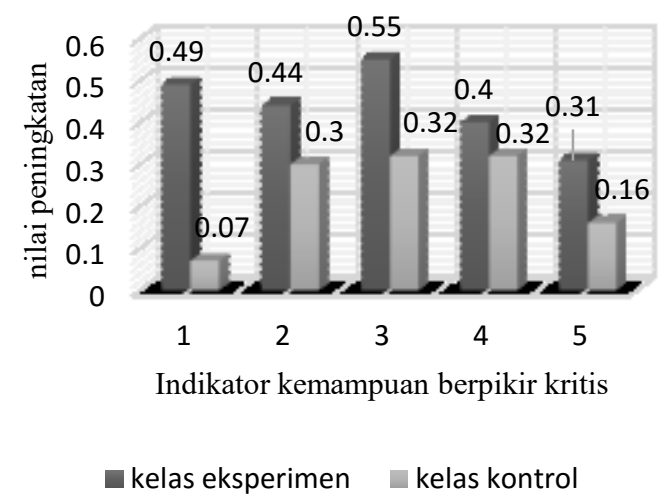

Gambar 1 sebagai berikut.

Gambar 1. Data Peningkatan Kemampuan Berpikir Kritis

Keterangan :

(1) Klarifikasi dasar; (2) Keputusan dasar; (3) Inferensi; (4) Penjelasan lebih lanjut; (5) Menalar dan pengintegrasian.

Berdasarkan data pada Gambar 1 diketahui bahwa indikator klarifikasi dasar berkriteria sedang pada kelas eksperimen dengan hasil N-gain 0,49 dan untuk kelas kontrol berkriteria rendah dengan nilai 0,07 . Terdapat perbedaan yang signifikan antara peningkatan pada kedua kelas, hal ini diakibatkan karena salah satu fase model learning cylce $5 E$ yang digunakan pada kelas eksperimen mendukung indikator tersebut. Fase yang dimaksud adalah fase explanation (penjelasan). Pada fase ini peserta didik menyampaikan pendapat sendiri mengenai pengetahuan yang telah didapatkan sebelumnya pada fase exploration. Melalui fase ini mereka dituntut untuk dapat menganalisis pendapat yang disampaikan dengan cara mengidentifikasi alasan mengenai konsep tertentu.

Pada indikator keputusan dasar berkriteria sedang pada kedua kelas dengan masing-masing nilai yang didapatkan yaitu 0,44 pada kelas eksperimen dan 0,30 pada kelas kontrol. Perbedaan peningkatan ini dapat disebabkan karena pada kelas eksperimen informasi atau pengetahuan yang didapatkan dicari sendiri dengan menggunakan berbagai sumber, lain halnya dengan kelas kontrol yang telah diberikan umpan terlebih dahulu oleh guru sebelum bekerja 
mandiri, dengan membiasakan peserta didik untuk mandiri dapat berpengaruh terhadap kemampuan untuk megingat suatu konsep dalam jangka waktu yang lama, karena konsep yang diperoleh bukan dalam bentuk hafalan melainkan suatu pengetahuan yang didapatkan secara langsung dan tersimpan dalam memori jangka panjang.

Indikator yang ketiga yaitu inferensi merupakan indikator yang paling dominan peningkatannya berkriteria sedang pada kedua kelas dengan nilai peningkatannya yaitu 0,55 pada kelas eksperimen dan 0,32 pada kelas kontrol. Peningkatan pada kelas eksperimen dapat terjadi karena pada setiap pertemuannya dirancang percobaan yang mengarahkan peserta didik untuk melakukan inferensi. Begitu juga pada kelas kontrol walaupun tidak melakukan inferensi namun mereka melakukan kegiatan menyimpulkan pada akhir kegiatan, sehingga dapat dikatakan bahwa pembiasaan pada proses pembelajaran memberikan pengaruh terhadap indikator ini.

Indikator yang keempat yakni penjelasan lebih lanjut pada kelas eksperimen dan kelas kontrol berturut-turut mengalami peningkatan sebesar 0,40 dan 0,32 yang berkategori sedang. Salah satu fase model pembelajaran pada kelas ekperimen yang berpengaruh adalah fase elaboration (elaborasi). Disini guru menantang dan memperluas pengetahuan yang telah didapatkan sebelumnya dengan memberikan latihan soal berbentuk aplikasi yang disajikan dalam lembar kerja peserta didik, melalui pengalaman-pengalaman pengetahuan yang baru, mereka dapat mendefinisikan istilah dan mempertimbangkan suatu definisi atau konsep dengan lebih jelas karena mereka menentukan sendiri asumsiasumsi (alasan yang lebih kuat) untuk konsep atau definisi tersebut.

Indikator yang kelima yaitu menalar dan pengintegrasian merupakan indikator yang paling rendah peningkatannya pada kelas eksperimen walaupun masih berada pada kriteria sedang. Begitu juga halnya dengan kelas kontrol yang memiliki kriteria rendah dengan nilai $\mathrm{N}$-gain sebesar 0,16. Kurangnya penalaran yang diintegrasikan dengan pemikiran pengandaian pada proses diskusi menjadi penyebab mengapa indikator ini memiliki peningkatan yang rendah.

Berdasarkan data hasil penelitian, nilai rata-rata tes awal berpikir kritis peserta didik pada kedua kelas berkategori sangat kurang kritis yaitu 32,90 pada kelas eksperimen dan 29,71 pada kelas kontrol. Tingkat kemampuan berpikir kritis peserta didik pada kedua kelas berada pada tingkat berpikir paling rendah, Setelah diberikan perlakuan pada kelas eksperimen menggunakan model learning cycle $5 E$ dan kelas kontrol menggunakan model cooperative learning tipe $S T A D$ terlihat perubahan yang signifikan terjadi pada kelas eksperimen. Tes akhir yang didapatkan kelas eksperimen sebesar 63,55 berada pada kategori kritis, sedangkan untuk kelas kontol tes akhir yang didapatkan sebesar 40,44 masih berada pada kategori sangat kurang kritis, seperti yang ditampilkan pada Gambar 2 berikut.

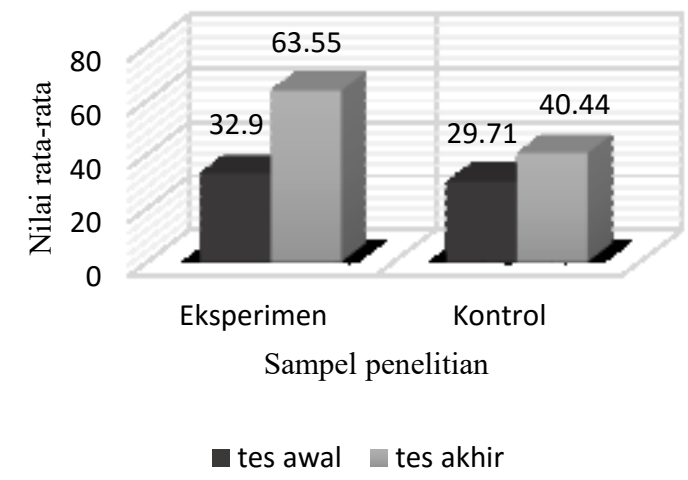

Gambar 2. Nilai rata-rata tes awal dan tes akhir kelas eksperimen dan kelas kontrol

Hal ini mengindikasikan bahwa proses pembelajaran yang berlangsung selama ini belum mampu meningkatkan kemampuan berpikir kritis karena aspek kognitif hanya ditekankan pada hasil bukan pada aspek proses yang melibatkan kemampuan berpikir kritis, sehingga kemampuan berpikir kritis yang dimiliki menjadi rendah, karena berpikir kritis terdiri dari tiga bagian yaitu (1) mengajukan pertanyaan berkaitan dengan apa yang perlu ditanyakan, mengajukan pertanyaan yang baik, pertanyaan yang masuk ke inti permasalahan. (2) usaha mencoba untuk menjawab pertanyaan melalui penalaran, dan (3) kepercayaan pada hasil penalaran (Herayanti \& Habibi, 2015). Selain itu, penyebab lainnya dapat disebabkan karena kedua kelompok sampel belum memperoleh materi usaha dan energi yang sesuai dengan jenjangnya melainkan hanya materi pengenalan usaha dan energi pada jenjang SMP. Nilai rata-rata tes awal kemampuan berpikir kritis ini kemudian dijadikan sebagai tolak ukur untuk melihat peningkatan kemampuan berpikir kritis peserta didik pada hasil tes akhir. 
Nilai rata-rata tes akhir kelas eksperimen sebesar 63,55 berkategori kritis sedangkan kelas kontrol sebesar 40,44 berkategori sangat kurang kritis. Kedua data tersebut lalu diolah menggunakan rumus $\mathrm{N}$-gain sehingga hasilnya ditunjukkan pada Gambar 3 berikut.

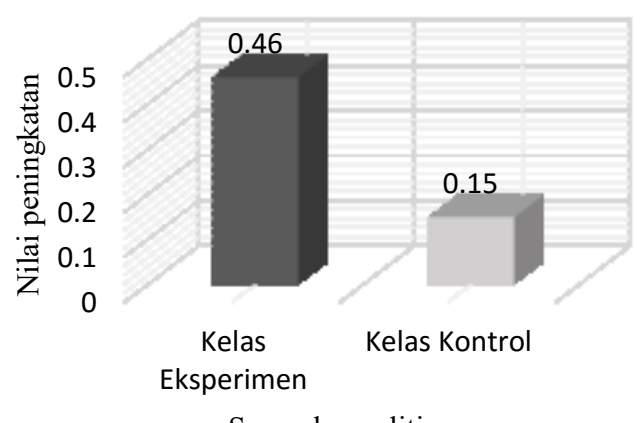

Gambar 3. Peningkatan nilai rata-rata

Jika ditinjau berdasarkan rumus $\mathrm{N}$-gain maka nilai rata-rata kemampuan berpikir kritis kelas eksperimen setelah diberikan perlakuan mengalami peningkatan yang signifikan dengan nilai sebesar 0,46 berkategori sedang. Berbeda halnya dengan kelas kontrol yang mengalami peningkatan dengan nilai Ngain 0,15 berkategori rendah. Perbedaan hasil tes akhir berdasarkan nilai rata-rata kedua kelas dan uji hipotesis ini menunjukkan bahwa penerapan model Learning Cycle $5 E$ berpengaruh terhadap kemampuan berpikir kritis. Hal tersebut karena model ini dapat melibatkan peserta didik secara optimal dalam proses pembelajaran, sehingga mereka aktif untuk mendapatkan pengetahuan melalui serangkaian kegiatan yang melatih untuk menemukan pengetahuannya sendiri. Keaktifan tersebut menyebabkan meningkatnya kemampuan berpikir kritis. Hal ini sesuai dengan apa yang dikemukakan oleh Udayani, et al (2014), bahwa kemampuan berpikir kritis akan berkembang jika selalu dihadapkan pada suatu permasalahan.

Pembelajaran yang menuntut keterlibatan secara optimal dalam proses belajar dapat meningkatkan kemampuan berpikir kritis. Hal yang sejalan dengan apa yang dikemukakan oleh Snyder \& Snyder (2008), lingkungan belajar yang melibatkan keaktifan dalam penyelidikan (penelitian) suatu informasi dan mengaplikasikan pengetahuan mereka dapat meningkatkan keterampilan berpikir kritis.
Hasil analisis dengan menggunakan uji N-gain didapatkan hasil bahwa secara garis besar peningkatan kemampuan berpikir kritis yang lebih tinggi terjadi pada kelas eksperimen dengan kelima indikatornya berada pada kriteria sedang. Berbeda halnya dengan kelas kontrol yang mengalami peningkatan dengan kriteria sedang hanya terdapat pada tiga indikator saja, untuk dua indikator lainnya berada pada tingkatan rendah.

Proses pembelajaran yang berlangsung pada kelas eksperimen dari kegiatan awal sampai kegiatan akhir menunjukkan adanya latihan untuk membentuk kemampuan berpikir kritis. Pada awal kegiatan sebelum praktikum dimulai, peserta didik dituntut untuk merumuskan hipotesis di LKPD dengan dibimbing oleh guru. Merumuskan hipotesis merupakan salah satu bagian dari kemampuan berpikir kritis. Pada kegiatan akhir juga dilakukan latihan mengembangkan kemampuan berpikir kritis. Pada bagian ini semua kelompok diminta untuk mengemukakan hasil diskusi berupa jawaban dari pertanyaan-pertanyaan yang ada di LKPD dengan menjawab soal yang berbeda. Hal ini bertujuan untuk memberikan penjelasan terhadap apa yang telah dikerjakan dan didiskusikan bersama dengan anggota kelompok mereka, sehingga mereka terlatih untuk aktif menyampaikan pendapat di depan kelas.

Aspek-aspek kemampuan berpikir kritis yang harus dicapai peserta didik lebih banyak diaplikasikan dalam penerapan model learning cycle $5 E$ dibandingkan dengan model cooperative learning tipe $S T A D$. Pada model learning cycle $5 E$ ini, peserta didik melakukan kegiatan terstruktur berupa lembar kegiatan percobaan untuk menyelidiki dan merumuskan sendiri konsep yang ditemukan. Kegiatan awal yang dilakukan yaitu memahami rumusan masalah yang telah diberikan oleh guru, kemudian dari rumusan masalah tersebut membuat hipotesis yang relevan, selanjutnya melakukan pengamatan dan percobaan, mengalisis data, membuat inferensi, menyelesaikan soal dengan penjelasan lebih lanjut, menalar dan mengintegrasikan, serta yang terakhir adalah berdiskusi dan mengkomunikasikan hasil. Adapun kegiatan yang dilakukan dalam model cooperative learning tipe $S T A D$ yaitu melakukan pengamatan dan percobaan, kemudian menjawab LKPD yang berkaitan dengan kegiatan pengamatan dan percobaan, serta melakukan kegiatan diskusi atau berkomunikasi. 
Rangkaian pembelajaran yang diterapkan pada kelas eksperimen menunjukkan terdapat proses untuk melatih keterampilan berpikir kritis karena keterampilan berpikir kritis tidak akan berkembang apabila tidak dilatih. Seperti yang dikemukakan oleh Snyder \& Snyder (2008) keterampilan berpikir kritis membutuhkan latihan, praktik, dan kesabaran. Keterampilan berpikir kritis tidak terjadi secara lahiriah, tetapi perlu dilatih dengan tujuan untuk menyiapkan peserta didik menjadi seorang pemikir kritis (Rahma, 2012).

Kegiatan-kegiatan dalam model learning cycle $5 E$ merupakan sarana yang lebih tepat dan efektif dalam pencapaian indikator-indikator kemampuan berpikir kritis. Dikuatkan oleh penelitian sebelumnya menunjukkan hal yang sama dengan hasil penelitian ini, seperti penelitian yang dilakukan oleh Prayogi, et al (2013) yang menyebutkan bahwa dengan penggunaan model learning cycle $5 E$ dapat memberikan tantangan pada peserta didik sehingga mereka bisa memperoleh kepuasan dengan menemukan pengetahuan baru bagi dirinya sendiri serta mengembangkan keterampilan berpikir kritis setiap peserta didik. Sehingga dapat disimpulkan bahwa dengan menggunakan model learning cycle $5 E$ dapat lebih mengembangkan kemampuan berpikir kritis peserta didik daripada menggunakan model cooperative learning tipe STAD.

\section{PENUTUP}

Berdasarkan hasil penelitian dapat disimpulkan bahwa ada pengaruh model learning cycle $5 E$ (Engage, Explore, Explain, Elaboration, \& Evaluate) terhadap kemampuan berpikir kritis peserta didik kelas X MAN 1 Mataram.

Penggunaan model learning cycle 5E (Engage, Explore, Explain, Elaboration, \& Evaluate) lebih mampu untuk meningkatkan kemampuan berpikir kritis peserta didik daripada menggunakan model cooperative learning tipe STAD.

\section{DAFTAR PUSTAKA}

Ennis R H. (2011). The Nature of Critical Thinking: An Outline of Critical Thinking Dispositions and Abilities. University of Illinois. On line at http://faculty.education.illinois.edu/rhennis/do cuments/TheNatureofCriticalThinking_51711_ 000.pdf [diakses tanggal 1 Oktober 2016].
Gunawan, G., \& Liliasari, L. (2013). Model virtual laboratory fisika modern untuk meningkatkan disposisi berpikir kritis calon guru. Jurnal Cakrawala Pendidikan, 5(2), 185-199.

Handriani, L.S., Harjono, A., \& Doyan, A. (2015). Pengaruh Model Pembelajaran Inkuiri Terstruktur dengan Pendekatan Saintifik Terhadap Kemampuan Berpikir Kritis dan Hasil Belajar Fisika Siswa. Jurnal Pendidikan Fisika dan Teknologi, 1(3), 210-220.

Herayanti, L., \& Habibi, H. (2015). Model Pembelajaran Berbasis Masalah Berbantuan Simulasi Komputer untuk Meningkatkan Keterampilan Berpikir Kritis Calon Guru Fisika. Jurnal Pendidikan Fisika dan Teknologi, 1(1), 61-66.

Hikmawati. (2015). Pembelajaran Fisika dengan Model Siklus Belajar 5E (Engage, Explore, Explain, Elaborate, Evaluate) Sebagai Upaya Meningkatkan Kecakapan Hidup Siswa. Jurnal Pendidikan Fisika dan Teknologi, 1(1), 24-37.

Johnson, E.B. (2008). Contextual Teaching and Learning: Menjadikan Kegiatan BelajarMengajar Mengasyikkan dan Bermakna. Diterjemahkan oleh Ibnu Setiawan. Bandung: Penerbit MLC.

Prayogi, S., Hidayat, S., \& Armansyah. (2013). Implementasi Model Pembelajaran 5E untuk Meningkatkan Hasil Belajar dan Kemampuan Berpikir Kritis Siswa. Jurnal Lensa Kependidikan Fisika, 1(1), 37-42.

Rahma, A.N. (2013). Pengembangan Perangkat Pembelajaran Model Inkuiri Berpendekatan SETS Materi Kelarutan dan Hasil Kali Kelarutan untuk menumbuhkan Keterampilan Berpikir Kritis dan Empati Siswa Terhadap Lingkungan. Journal of Education Research and Evaluation, 1(2), 133-138.

Setyosari, P. (2013). Metode Penelitian Pendidikan dan Pengembangan. Jakarta: Kencana Prenadamedia Group.

Snyder, L.G. \& Snyder, M.J. (2008). Teaching Critical Thinking and Problem Solving Skills. The Delta Pi Epsilon Journal, 2, Spring/Summer, 2008: 90-99. Diakses tanggal 2 Mei 2015.

Suprijono, A. (2011). Model-Model Pembelajaran. Jakarta : Gramedia Pustaka Jaya.

Udayani, P.A., Kusmariyatni, N., \& Wibawa, I.M.C. (2014). Pengaruh Model Siklus Belajar 5E Terhadap Kemampuan Berpikir Kritis IPA Siswa Kelas IV SD di Desa Kalibukbuk. eJournal MIMBAR PGSD Universitas 
Pendidikan Ganesha Jurusan PGSD, 1(2), 110.

Yuliati, D.I., Yulianti, D., \& Khanafiyah, S. (2011).

Pembelajaran Fisika Berbasis Hands On Activities Untuk Menumbuhkan Kemampuan Berpikir Kritis dan Meningkatkan Hasil Belajar Siswa SMP. Jurnal Pendidikan Fisika Indonesia, 7, 23-27. 